\section{Daratumumab, an original approach for treating multi-refractory autoimmune cytopenia}

Immune thrombocytopenia (ITP) and warm autoimmune hemolytic anemia (AIHA) are antibody-mediated autoimmune diseases in which plasma cells secrete pathogenic antibodies directed against platelet and red blood cell antigens. ${ }^{1}$ Some patients show no response to first- or second-line treatments, including corticosteroids, rituximab, immunosuppressive drugs, splenectomy and, in the case of ITP, thrombopoietin receptor agonists, a situation that increases the risk of morbidity and mortality. ${ }^{2,3}$ In these refractory cases, persistent autoreactive long-lived plasma cells in the bone marrow could explain treatment failure.

Daratumumab, an anti-CD38 monoclonal antibody developed to target tumoral plasma cells in multiple myeloma, ${ }^{4}$ was recently found to be effective in antibody-mediated diseases, such as autoimmune cytopenia following hematopoietic stem cell transplantation ${ }^{5-11}$ and systemic lupus. ${ }^{12}$ Here we report the characteristics and outcome of patients who received daratumumab "off label" (compassionate use) for severe refractory ITP or warm AIHA.

Table 1. Characteristics and outcomes of patients.

\begin{tabular}{|c|c|c|c|c|c|c|c|c|c|c|c|c|c|}
\hline $\begin{array}{l}\text { Patient } \\
\#\end{array}$ & $\begin{array}{l}\text { Age/ } \\
\text { Sex }\end{array}$ & $\begin{array}{l}\text { Autoimmune } \\
\text { cytopenia }\end{array}$ & $\begin{array}{l}\text { Disease } \\
\text { duration } \\
\text { (months) }\end{array}$ & $\begin{array}{c}\text { Active or } \\
\text { past underlying } \\
\text { disease }\end{array}$ & $\begin{array}{l}\text { Time } \\
\text { from last } \\
\text { rituximab } \\
\text { infusion }\end{array}$ & $\begin{array}{l}\text { Previous } \\
\text { splenectomy }\end{array}$ & $\begin{array}{c}\text { Other previous } \\
\text { therapies }\end{array}$ & $\begin{array}{l}\text { Number of } \\
\text { laratumumalb } \\
\text { infusions }\end{array}$ & $\begin{array}{l}\text { Treatments R } \\
\text { b given with } \\
\text { daratumumab }\end{array}$ & Response & $\begin{array}{l}\text { Time to } \\
\text { response } \\
\text { (days) }\end{array}$ & $\begin{array}{l}\text { Duration of } \\
\text { response } \\
\text { (months) }\end{array}$ & f Relapse \\
\hline 1 & $34 / \mathrm{M}$ & ITP & 95 & $\begin{array}{l}\text { Evans syndrome, } \\
\text { antiphospholipid } \\
\text { syndrome }\end{array}$ & 3 & Yes & $\begin{array}{l}\text { CS (resistant), } \\
\text { IVIg (response), } \\
\text { HCQ (failure), } \\
\text { eltrombopag (failure), } \\
\text { MMF (failure), } \\
\text { CSA (failure) }\end{array}$ & 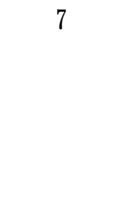 & None & CR & 7 & 12 & No \\
\hline 2 & $35 / \mathrm{F}$ & ITP & 128 & Evans syndrome & 98 & $\begin{array}{l}\text { No } \\
\text { (obesity) } \\
\\
\text { r } \\
\text { e } \\
\end{array}$ & $\begin{array}{l}\text { CS (resistant), } \\
\text { IVIg (response), } \\
\text { romiplostim (failure), } \\
\text { eltrombopag (failure), } \\
\text { MMF (failure), } \\
\text { AZA (failure), } \\
\text { CSA (failure), } \\
\text { CYC (failure) }\end{array}$ & 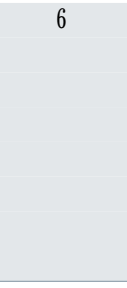 & None & CR & 35 & 3 & Yes \\
\hline 3 & $70 / \mathrm{M}$ & ITP & 103 & $\begin{array}{l}\text { Recurrent venous } \\
\text { thrombosis }\end{array}$ & 21 & Yes & $\begin{array}{l}\text { CS (dependant), } \\
\text { MMF (failure), } \\
\text { sirolimus (failure), } \\
\text { CSA (failure) }\end{array}$ & 4 & None & Failure & NA & $\mathrm{NA}$ & No \\
\hline 4 & $20 / \mathrm{F}$ & ITP & 174 & $\begin{array}{l}\text { Ischemic stroke } \\
\text { with hemorrhagic } \\
\text { transformation }\end{array}$ & 10 & r & $\begin{array}{l}\text { CS (resistant), } \\
\text { IVIg (response), } \\
\text { romiplostim (failure), } \\
\text { eltrombopag (failure), } \\
\text { MMF (failure), } \\
\text { disulone (failure) }\end{array}$ & 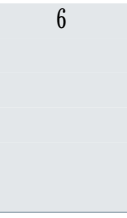 & $\begin{array}{l}\text { High-dose CS } \\
\text { and IVIg }\end{array}$ & Failure & NA & $\mathrm{NA}$ & $\mathrm{NA}$ \\
\hline 5 & $35 / F$ & $\begin{array}{l}\text { ITP } \\
\text { AGS }\end{array}$ & 24 & $\begin{array}{c}\text { Hodgkin } \\
\text { disease ( } 9 \\
\text { years before } \\
\text { daratumumab) }\end{array}$ & 15 & $\begin{array}{l}\mathrm{r} \\
\mathrm{e}\end{array}$ & $\begin{array}{c}\text { For AGS: } \\
\text { CS (failure), } \\
\text { IVIg (failure), } \\
\text { MMF (failure). } \\
\text { For ITP: } \\
\text { romiplostim (failure), } \\
\text { eltrombopag (failure), } \\
\text { disulone (failure) }\end{array}$ & (1) & None & Failure & NA & $\mathrm{NA}$ & $\begin{array}{c}\text { Yes } \\
\text { (at } 6 \text { months, } \\
\text { ITP) }\end{array}$ \\
\hline 6 & $69 / \mathrm{M}$ & ITP & 18 & Evans syndrome & 12 & $\begin{array}{r}\text { No } \\
r \\
\text { eltro }\end{array}$ & $\begin{array}{l}\text { CS (response), } \\
\text { IVIg (response), } \\
\text { romiplostim (failure), } \\
\text { ombopag (response ther } \\
\text { adverse event) }\end{array}$ & hen & $\begin{array}{l}\text { High-dose CS } \\
\text { and IVIg }\end{array}$ & Failure & NA & $\mathrm{NA}$ & $\mathrm{NA}$ \\
\hline 7 & $55 / \mathrm{F}$ & $\begin{array}{l}\text { Warm } \\
\text { AIHA }\end{array}$ & 74 & Evans syndrome & 3 & No & CS (response) & c & $\begin{array}{l}\text { High-dose CS with } \\
\text { complete weaning } \\
\text { at } 6 \text { weeks }\end{array}$ & th CR & 2 & 9 & Yes \\
\hline 8 & $55 / \mathrm{F}$ & $\begin{array}{l}\text { Warm } \\
\text { AlHA }\end{array}$ & 26 & Evans syndrome & 5 & Yes & $\begin{array}{l}\text { CS (response), } \\
\text { AZA (failure), } \\
\text { CSA (failure), } \\
\text { everolimus (failure), } \\
\text { bortezomib (failure) }\end{array}$ & 11 & None & Failure & $\mathrm{NA}$ & $\mathrm{NA}$ & $\mathrm{NA}$ \\
\hline
\end{tabular}


We conducted an observational, retrospective study including patients $>18$ years who were treated with daratumumab for ITP and/or warm AIHA (primary or secondary) according to international criteria. ${ }^{13,14}$ The patients were identified through the French National Reference Center for Adult Immune Cytopenia network from November 2019 to November 2021. Any patient who

A
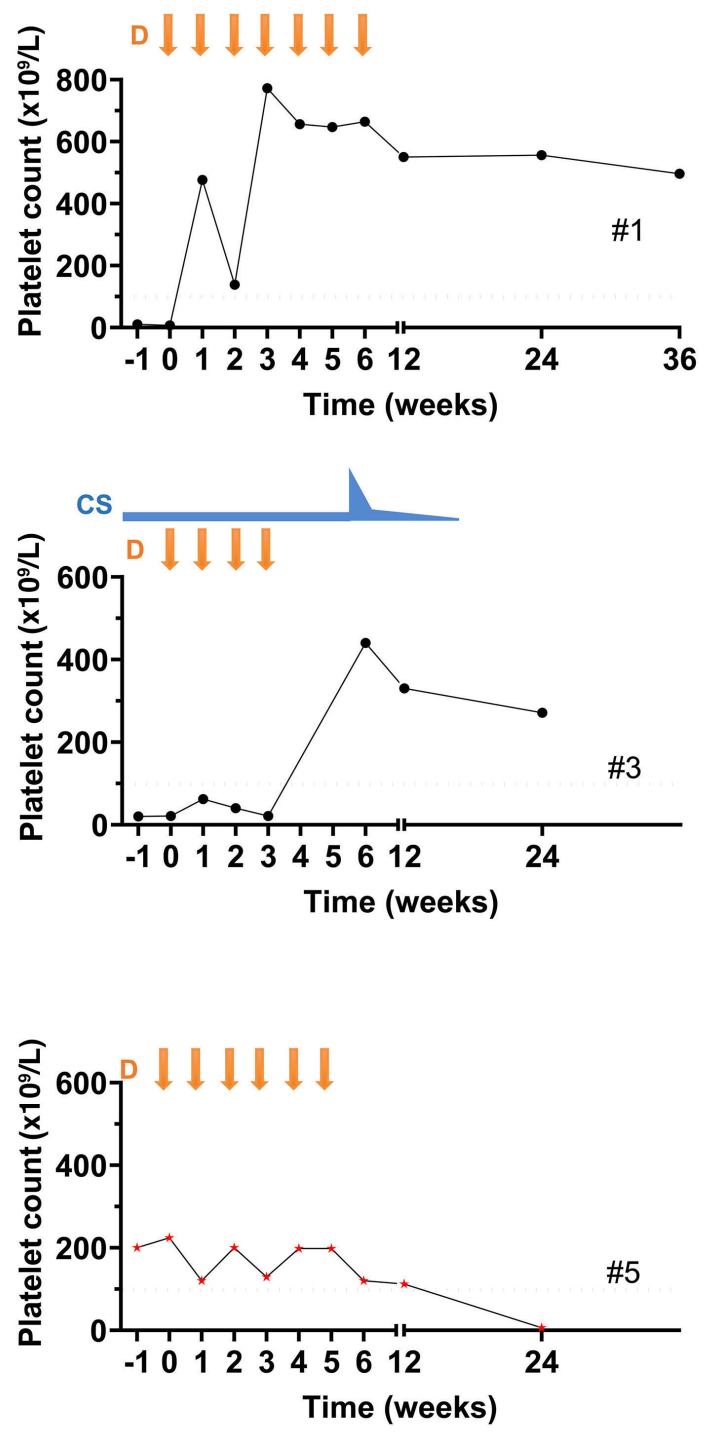

B

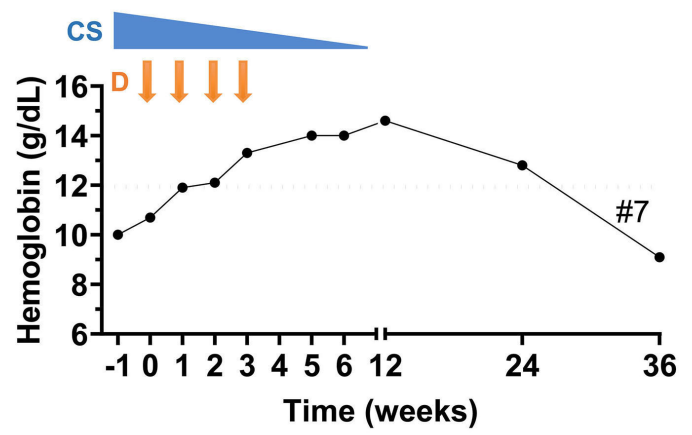

opposed data collection was not included. All patients were informed and gave consent to 'off-label' use of daratumumab. The initial treatment regimen was extrapolated from the one commonly used in myeloma ${ }^{4}$ (i.e., at least 4 daratumumab infusions at a dose of $16 \mathrm{mg} / \mathrm{kg}$ per week combined with oral dexamethasone $20 \mathrm{mg}$ before each infusion). For ITP, complete response was defined as a
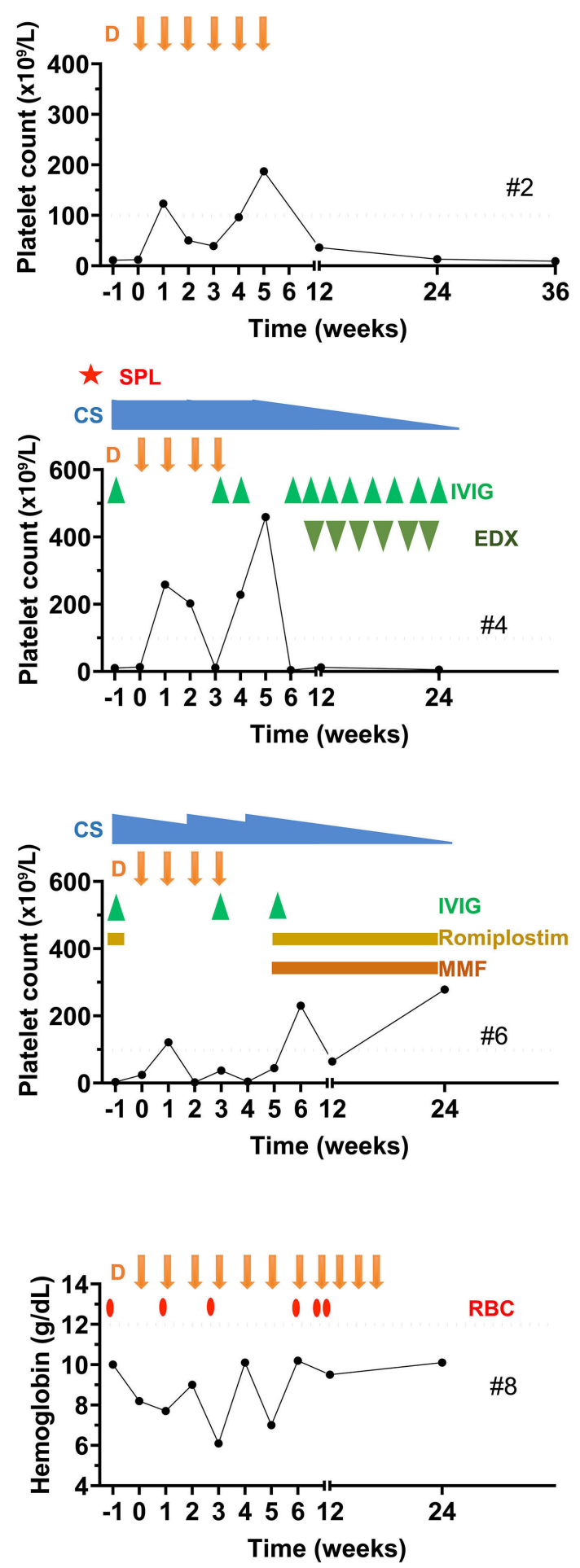

Figure 1. Autoimmune cytopenia evolution after daratumumab treatment. (A) Evolution of platelet counts in patients with immune thrombocytopenia after daratumumab. Patient \#5 had acquired Glanzmann syndrome and red stars indicate hemorrhagic symptoms. (B) Evolution of hemoglobin levels in patients with warm autoimmune hemolytic anemia after daratumumab. Week 0 corresponds to the first daratumumab infusion (orange "D"). CS: corticosteroids, CYC: cyclophosphamide; IVIG: intravenous immunoglobulin, MMF: mycophenolate mofetil, RBC: red blood cell transfusion, SPL: splenectomy. 
platelet count $>100 \times 10^{9} / \mathrm{L}$ and response as a platelet count between 30 and $100 \times 10^{\circ} / \mathrm{L}$ with at least a 2 -fold increase from baseline. ${ }^{13}$ For warm AHAI, complete response was defined as a hemoglobin level $\geq 12 \mathrm{~g} / \mathrm{dL}$ in the absence of recent transfusion and response as a hemoglobin level $\geq 10$ $\mathrm{g} / \mathrm{dL}$ with an increase of at least $2 \mathrm{~g} / \mathrm{dL}$ from the pre-treatment level in the absence of recent transfusion $\quad<1$ month) ${ }^{14}$ Patients who required any other treatment for autoimmune cytopenia including rescue therapy $>6$ weeks after the first daratumumab infusion were considered non-responders regardless of platelet or hemoglobin levels. The first daratumumab infusion was considered day 0 for subsequent time points. Clinical and biological data were collected with a standardized form. The study received institutional review board approval (00011558, UPEC University, AP-HP).

Eight patients (5 females [62.5\%]; median age 45 years [range, 34-70]) from six participating centers received daratumumab for refractory $\operatorname{ITP}(n=5)$, acquired Glanzmann syndrome with former ITP and normal platelet count $(n=1)$ or warm AIHA $(n=2)$. Six had secondary ITP or warm AIHA, five had Evans syndrome with no underlying immunodeficiency (including one patient with primary antiphospholipid syndrome) and one patient had a history of Hodgkin lymphoma that was cured (\#5) 9 years before the onset of ITP/Glanzmann syndrome (Table 1). At the time of starting daratumumab treatment, the median disease duration was 84.5 months (range, 18174). The median number of previous therapies was 6 [range, 6-11]. No patients had shown a response to their last course of rituximab (except one patient who relapsed at 3 months) and five had undergone splenectomy (Table 1).

For the five patients with ITP, the median platelet count was $11 \times 10^{9} / \mathrm{L}$ (range, $0-21 \times 10^{9} / \mathrm{L}$ ), and all patients had skin and/or mucosal bleeding within the month before daratumumab. Two patients (\#1, \#2) achieved complete responses at 4 weeks (Figure 1). Patient \#1 had a history of arterial and venous antiphospholipid syndrome, with strong positivity of lupus anticoagulant and IgM anti$\beta 2 \mathrm{GP1}$ antibodies without IgG or anticardiolipin antibodies. Nine months after daratumumab, the patient had no remaining IgM anti- $\beta 2$ GP 1 antibodies, and lupus anticoagulant was barely detectable. He had no recurrence of thrombosis during follow-up with ongoing vitamin $\mathrm{K}$ antagonist treatment.

Patient \#3 was dependent on corticosteroids and had no response at 4 weeks, which resulted in a transient increase in corticosteroid doses. However, he achieved long-lasting complete response even after corticosteroid discontinuation 24 weeks after starting daratumumab, suggesting a delayed effect of anti-CD38 treatment. The two remaining patients (\#4, \#6) showed no response after daratumumab.

One 35-year-old patient (\#5) had chronic ITP and, after splenectomy, developed acquired Glanzmann thrombasthenia with bleeding despite normal platelet counts. She had anti-GPIIbIIIa antibodies, and platelet aggregation studies showed no aggregation with adenosine diphosphate, epinephrine, or arachidonic acid, with reverse ristocetin agglutination. She showed no response to intravenous immunoglobulins, corticosteroids or mycophenolate mofetil and was given daratumumab, with no response for hemorrhagic symptoms. She eventually had an ITP relapse 24 weeks after starting daratumumab.

For the two patients with warm AIHA, the median baseline hemoglobin level was $9.4 \mathrm{~g} / \mathrm{dL}$ (range, 8.2-10.7), median reticulocyte count $174 \times 10^{9} / \mathrm{L}$ (range, 124-225 $\mathrm{x} 10^{\circ} / \mathrm{L}$ ), and median bilirubin level $27 \mu \mathrm{mol} / \mathrm{L}$ (range, 24
$30)$. For both patients, the haptoglobin level was $<0.1$ $\mathrm{mg} / \mathrm{L}$, and the median lactate dehydrogenase level was 2.8 times the normal range (range, 1.34-4.2). Both had a history of ITP but normal platelet counts at the time of the first daratumumab infusion. One patient achieved a complete response after four cycles of daratumumab but relapsed after 9 months, and one had no response after 11 cycles, despite a progressive decrease in transfusion requirement after 3 months.

After a median follow-up of 24 weeks (range, 24-36) from the first infusion of daratumumab, five patients experienced at least one moderate adverse event. Three (\#3, \#7 and \#8) had a minor reaction at the first daratumumab infusion. No further infusion-related reactions occurred afterwards. Two patients had infectious events: patient \#5 had bacterial pneumonia requiring hospitalization at 4 weeks and patient \#8 had COVID-19 pneumonia requiring hospitalization and convalescent plasma therapy because of persistent symptoms at 20 weeks (chronic viremia without seroconversion). The median gammaglobulin level decreased from $7.1 \mathrm{~g} / \mathrm{L}$ (range, 4.8-16.2) before treatment to $4.2 \mathrm{~g} / \mathrm{L}$ (range, 3.5-7.6) at week 12 and $6.1 \mathrm{~g} / \mathrm{L}$ (range, 6-15.5) at week 36 (Figure 2). Hypogammaglobulinemia (i.e., gammaglobulin level $<6$ $\mathrm{g} / \mathrm{L}$ ) was observed in five out of six patients at 12 weeks (after exclusion of 2 patients who had received intravenous immunoglobulins in the 3 weeks before dosage).

Although this study has some limitations, including its uncontrolled design and the heterogeneity of the patients, our results suggest that daratumumab may be effective for some patients with refractory ITP and/or warm AIHA, two conditions associated with a high mortality rate..$^{2,3}$ Three of eight patients achieved a complete response and one patient a delayed response despite previous failure to respond to several treatment lines including rituximab, splenectomy and at least one immunosuppressant. One patient showed complete disappearance of antiphospholipid antibodies. Whether depletion of CD38-positive cells correlates with response and/or relapses remains an open question that should be addressed in future studies.

We observed rapid response (within 1 month) among responders, suggesting that four daratumumab infusions are sufficient to induce remission in responders. However, the optimal number of infusions remains to be determined. Importantly, two patients with an initial complete response eventually relapsed at 3 and 9 months, suggesting that plasma cell reconstitution had occurred. In these patients, the ongoing autoimmune B-cell response may not have been affected by daratumumab, which targets plasma cells and spares CD38-negative B cells. Thus, combining B-cell depletion with an anti-CD20 antibody and daratumumab may impair the generation of newly formed autoreactive plasma cells and prevent relapse. ${ }^{15}$

In this particular group of immunocompromised patients, the risk of severe infection was a main concern. All but one experienced profound although transient hypogammaglobulinemia, and two had a symptomatic infection. Therefore, the risk/benefit balance of such therapy should be carefully discussed according to the patient's clinical history.

In conclusion, daratumumab may provide clinical benefit in a subset of patients with ITP or warm AIHA refractory to standard therapy. However, the efficacy seems relatively modest and hypogammaglobulinemia exposes patients to a risk of infection. Future prospective trials will evaluate the use of CD38-directed monoclonal antibodies for the management of patients with immune cytopenias, such as daratumumab in ITP (NCT04703621) or isatuximab in warm AIHA (NCT04661033). 
Etienne Crickx, ${ }^{1}$ Sylvain Audia, ${ }^{2}$ Ailsa Robbins, ${ }^{3}$ David Boutboul, ${ }^{4}$ Thibault Comont, ${ }^{5}$ Morgane Cheminant, ${ }^{6}$ Eric Oksenhendler, ${ }^{4}$ Bertrand Godeau, ${ }^{1}$ Marc Michel' and Matthieu Mahevas ${ }^{1}$

${ }^{1}$ Service de Médecine Interne, Centre National de Référence des Cytopénies Auto-immunes de l'Adulte, Hôpital Henri Mondor Assistance Publique Hôpitaux de Paris, Université Paris Est Créteil, Créteil; ${ }^{2}$ Service de Médecine Interne et d'Immunologie Clinique, Centre Constitutif de Référence des Cytopénies Auto-immunes de l'Adulte, Hôpital François Mitterrand, Dijon Cedex; ${ }^{3}$ Service de Médecine Interne,Maladies Infectieuses, Immunologie Clinique, CHU Robert Debré, Reims; ${ }^{4}$ Service d'Immunologie Clinique, Hôpital Saint Louis, Paris, and Paris Université; ${ }^{5}$ Service de Médecine Interne et Immunopathologie, Institut Universitaire du Cancer Toulouse - Oncopôle, Toulouse and 'Service d'Hématologie Clinique, Hôpital Necker, Paris, France

Correspondence:

MATTHIEUMAHÉVAS - matthieu.mahevas@aphp.fr

doi:10.3324/haematol.2021.279232

Received: May 16, 2021.

Accepted: July 1, 2021.

Pre-published: August 5, 2021.

Disclosures: no conflicts of interest to disclose.

Contributions: EC and MMa designed the study and analyzed the data. EC, SA, AR, TC, DB, MC, EO, MMi, BG and MMa wrote the manuscript and included patients in the study.

Acknowledgments: we thank L. Languille for logistic coordination.

\section{References}

1. Audia S, Mahévas M, Samson M, Godeau B, Bonnotte B Pathogenesis of immune thrombocytopenia. Autoimmun Rev. 2017;16(6):620-632.

2. Mahévas M, Gerfaud-Valentin M, Moulis G, et al. Characteristics, outcome, and response to therapy of multirefractory chronic immune thrombocytopenia. Blood. 2016;128(12):1625-1630.

3. Barcellini W, Fattizzo B, Zaninoni A, et al. Clinical heterogeneity and predictors of outcome in primary autoimmune hemolytic anemia: a GIMEMA study of 308 patients. Blood. 2014;124(19):29302936.

4. Lonial S, Weiss BM, Usmani SZ, et al. Daratumumab monotherapy in patients with treatment-refractory multiple myeloma (SIRIUS): an open-label, randomised, phase 2 trial. Lancet. 2016;387(10027) 1551-1560.

5. Jain A, Gupta DK. Daratumumab for refractory warm autoimmune hemolytic anemia. Ann Hematol. 2021;100(5):1351-1353.

6. Cooling L, Hugan S. Daratumumab in combination with standard treatment for autoimmune hemolytic anemia in a pediatric patient. Transfusion. 2019;59(12):3801-3802.

7. Schuetz C, Hoenig M, Moshous D, et al. Daratumumab in lifethreatening autoimmune hemolytic anemia following hematopoietic stem cell transplantation. Blood Adv. 2018;2(19):2550-2553.

8. Blennerhassett R, Sudini L, Gottlieb D, Bhattacharyya A. Post-allogeneic transplant Evans syndrome successfully treated with daratumumab. Br J Haematol. 2019;187(2):e48-e51.

9. Even-Or E, Naser Eddin A, Shadur B, et al. Successful treatment with daratumumab for post-HSCT refractory hemolytic anemia. Pediatr Blood Cancer. 2020;67(1):e28010.

10. Driouk L, Schmitt R, Peters A, et al. Daratumumab therapy for post-HSCT immune-mediated cytopenia: experiences from two pediatric cases and review of literature. Mol Cell Pediatr. 2021;8(1):5.

11. Zaninoni A, Giannotta JA, Gallì A, et al. The immunomodulatory effect and clinical efficacy of daratumumab in a patient with cold agglutinin disease. Front Immunol. 2021;12:649441.

12. Ostendorf L, Burns M, Durek P, et al. Targeting CD38 with daratumumab in refractory systemic lupus erythematosus. $N$ Engl J Med. 2020;383(12):1149-1155.

13. Rodeghiero F, Stasi R, Gernsheimer T, et al. Standardization of terminology, definitions and outcome criteria in immune thrombocytopenic purpura of adults and children: report from an international working group. Blood. 2009;113(11):2386-2393.

14. Michel M, Terriou L, Roudot-Thoraval F, et al. A randomized and double-blind controlled trial evaluating the safety and efficacy of rituximab for warm auto-immune hemolytic anemia in adults (the RAIHA study). Am J Hematol. 2017;92(1):23-27.

15. Dossier C, Prim B, Moreau C, et al. A global antiB cell strategy combining obinutuzumab and daratumumab in severe pediatric nephrotic syndrome. Pediatr Nephrol. 2021;36(5):1175-1182. 